\title{
Factors Associated with Body Weight Attainment in Calves on Smallholder Dairy Farms in Tanzania
}

\author{
Jelly Senyangwa Chang'a ${ }^{1,2 *}$, Torleiv Løken², Robinson H. Mdegela ${ }^{3}$, Olav Reksen ${ }^{2}$ \\ ${ }^{1}$ Livestock Research Centre, Ministry of Livestock Development, Tanga, Tanzania \\ ${ }^{2}$ Department of Production Animal Clinical Sciences, Norwegian School of Veterinary Science, Oslo, Norway \\ ${ }^{3}$ Department of Veterinary Medicine and Public Health, Faculty of Veterinary Medicine, \\ Sokoine University of Agriculture, Morogoro, Tanzania \\ Email: *JellySenyangwa.Chang'a@stud.nvh.no, jelhas2002@yahoo.co.uk, \{Torleiv.Loken, Olav.Reksen\}@nvh.no, \\ mdegela@suanet.ac.tz,rmdegela@yahoo.com
}

Received January 25, 2012; revised February 22, 2012; accepted March 9, 2012

\begin{abstract}
In order to investigate associations between individual calf parameters and/or herd management practices and dairy calf body weight (BW) attainment in smallholder farms in Tanzania, a prospective study was carried out at 121 farms in Mvomero and Njombe districts and included 156 crossbred dairy calves. Information on management factors and sources of calf drinking water were collected by personal observation and interview during four visits. At each visit, BW assessments were conducted by the same veterinarian and blood samples collected. The blood samples were analyzed for hematological parameters, total blood protein, glucose, and serum phosphorus and urea. Low BW was associated with smaller amount of milk fed to calves, early weaning, birth during the wet season, and well/tap water as the main water source $(P<0.05)$. Low blood total protein, high urea, low phosphorus and low hemoglobin concentrations were also associated with retarded growth. These findings identified and quantified some critical factors that can guide farmers in improving calf performance on smallholder dairy farms in Tanzania. To improve calf BW, the protein and mineral fraction of the roughage should be increased and water supply should be improved. In conclusion, appropriate changes in milk feeding routines and breeding management would also be expected to improve productivity.
\end{abstract}

Keywords: Bodyweight; Calf, Hematology; Management; Smallholder Dairy Farmers

\section{Introduction}

A sustainable dairy production system depends on good herd management. Management practices throughout the rearing period affect the longevity of the dairy cow and thereby the total herd economy [1]. It is important to understand reasons for growth impairment in calves because growth influences the time of first breeding, as well as age and body weight (BW) at first calving. Infectious diseases seem unlikely to be the primary reason for impaired growth of smallholder dairy calves in Tanzania [2], and inadequate feeding is probably the major reason for retarded calf growth. Nutrition of young dairy calves is critical for their future productivity. During the first 1 to 2 months of life, dairy calves function primarily as monogastric animals [3], after which they begin to function as mature ruminants [4]. Adequate amounts of high quality colostrum at birth, sufficient quantities of milk, appropriate weaning management, sufficient intake of dry feed and water, and good disease control strategies are all of great importance for the overall well-being and

"Corresponding author. growth of young calves [5-7].

Hematological measurements are important indicators regarding suboptimal growth parameters and other stress factors [8]. A decrease in red blood cell mass causes reduced oxygenation, and associated compensatory mechanisms. These, in turn, result in subnormal growth that is associated with a wide range of conditions including anorexia, fever or lymphadenopathy [8].

Minerals are vital to animal health and productivity [9]. Phosphorus, the second most abundant mineral element in the animal body, is involved in control of appetite and in feed utilization efficiency [10]. Phosphorus deficiency results in inhibition of growth, loss of weight, and reduced appetite before signs in the bone system become apparent; clinical signs of phosphorus deficiency occur mainly in young animals [11]. Urea is the nitrogenous waste product of protein catabolism. Fluctuations in ruminant plasma urea concentrations reflect carbohydrate and protein availability [12]. Both energy and protein in animal rations are important for the well-being and growth of young animals [13].

Research on calf growth in Tanzania in relation to 
management practices and individual calf parameters is limited. Das et al., [14] reported positive associations between calf growth and amount of milk fed, and breed and parity of the dam. The objectives of our study were: 1) to determine which management factors had greatest impact on calf growth and to quantify the impact of these factors; 2) to identify calf-specific and herd-specific factors associated with $\mathrm{BW}$ attainment and to investigate their pathophysiological relationships with feedstuff and feeding management.

\section{Materials and Methods}

\subsection{The Study Area}

The study was conducted in 13 villages in the districts of Mvomero in Southeastern Tanzania, and Njombe in the Southern highlands of Tanzania. Further details of the study sites have been published previously [15].

\subsection{Animals}

A total of 156 calves on 121 smallholder dairy farms (72 from Mvomero and 84 from Njombe) were included in the study and data collected on at least one out of four farm visits. The calves were crossbred Friesian or Ayrshire and Tanzanian shorthorn zebu (TSHZ). All animals were ear tagged when first included in the study.

\subsection{Calf Examination and Management}

At each visit, calf BW was estimated using a heart girth measuring tape. Information on farm characteristics and management were collected by personal interview using a standardized record form. The calf-specific variables recorded included: district, date of birth, sex, breed, and weaning age. Farm-specific information included: record keeping, education in calf rearing, amount of milk fed to calf per day, type of milk feeding (bucket or suckling), time to first colostrum ingestion, amount of colostrum fed on first day, reason for rearing male calves, and drinking water source for calves. Water from rivers, streams, and shallow wells were classified as surface water, and water from taps and deep wells were classified as deep/tap water. Housing and hygiene was assessed by observation and recorded as either clean or dirty (Table 1).

\subsection{Blood Sampling and Analysis}

Over the course of the study, 498 blood samples were collected from the jugular veins of the calves, with each blood sample collected into three different vacutainer tubes; tubes with no additive (for urea and phosphorus), with fluoride (for glucose), and with heparin (for hematological parameters; packed cell volume (PCV), hemoglobin $(\mathrm{Hb})$ concentration, mean cell $\mathrm{Hb}$ concentration (MCHC), and total protein).

Table 1. Herd/management variables considered in analyses and their association with bodyweight (BW) attainment based on a univariate survival model using Kaplan-Meier estimator and the log rank test in 121 smallholder dairy farms in Tanzania.

\begin{tabular}{|c|c|c|c|c|}
\hline \multirow{2}{*}{ Factor } & \multirow{2}{*}{ Level (n) } & \multirow{2}{*}{$\mathrm{n} 100 \mathrm{~kg}$} & \multicolumn{2}{|c|}{ Log-rank test } \\
\hline & & & $P$ & Chi square \\
\hline \multirow{2}{*}{ District } & Mvomero (53) & 44 & \multirow{2}{*}{0.90} & \multirow{2}{*}{0.01} \\
\hline & Njombe (79) & 55 & & \\
\hline \multirow{2}{*}{ Sex } & Female (73) & 53 & \multirow{2}{*}{0.11} & \multirow{2}{*}{2.59} \\
\hline & Male (59) & 46 & & \\
\hline \multirow{2}{*}{ Season of birth } & Rainy (70) & 55 & \multirow{2}{*}{$<0.001$} & \multirow{2}{*}{14.69} \\
\hline & Dry (62) & 44 & & \\
\hline \multirow{2}{*}{ Age at weaning } & $\leq 16$ weeks $(91)$ & 72 & \multirow{2}{*}{0.04} & \multirow{2}{*}{4.07} \\
\hline & $>16$ weeks $(28)$ & 23 & & \\
\hline \multirow{2}{*}{ Water source } & Surface (19) & 19 & \multirow{2}{*}{$<0.001$} & \multirow{2}{*}{16.03} \\
\hline & Well/tap (113) & 80 & & \\
\hline \multirow{2}{*}{ Record keeping } & No (67) & 44 & \multirow{2}{*}{0.90} & \multirow{2}{*}{0.02} \\
\hline & Yes (64) & 54 & & \\
\hline Education in calf rearing & No (104) & 78 & 0.69 & 0.16 \\
\hline \multirow{2}{*}{ Kg milk pr calf/day } & $<3 \mathrm{~kg}(71)$ & 58 & \multirow{2}{*}{0.003} & \multirow{2}{*}{8.72} \\
\hline & $\geq 3 \mathrm{~kg}(46)$ & 33 & & \\
\hline \multirow{2}{*}{$\mathrm{Kg}$ colostrum first day } & $<3 \mathrm{~kg}(77)$ & 62 & \multirow{2}{*}{0.56} & \multirow{2}{*}{0.34} \\
\hline & $\geq 3 \mathrm{~kg}(45)$ & 30 & & \\
\hline \multirow{2}{*}{ Time to first colostrum } & $<120 \min (80)$ & 61 & \multirow{2}{*}{0.70} & \\
\hline & $\geq 120 \min (41)$ & 34 & & 0.15 \\
\hline Milk feeding & Suckling (112) & 87 & & \\
\hline Milk feeding & Bucket (13) & 11 & 0.45 & 0.57 \\
\hline Rearing of male colves & For selling (57) & 42 & 013 & 236 \\
\hline Rearing or male calves & For keeping (74) & 57 & 0.13 & 2.56 \\
\hline Housing conditions & Clean $(82)$ & 57 & 040 & 047 \\
\hline Housing conditions & Dirty (50) & 42 & 0.49 & $0.4 /$ \\
\hline
\end{tabular}


Serum was harvested from the clotted blood in the plain tube by centrifuging at $3000 \mathrm{rpm}$ for 10 minutes, and stored at $-20^{\circ} \mathrm{C}$ until analysis. Serum phosphorus and urea concentrations and plasma glucose concentrations and total protein were determined using commercial kits (BioSystems S.A., Costa Brava 30, Barcelona (Spain).

Packed cell volume was determined as described by Baker and Silverton [16]. Similarly, $\mathrm{Hb}$ was measured using the cyanmethaemoglobin method described by Baker and Silverton [16]. MCHC was calculated from the $\mathrm{Hb}$ concentration and PCV [8].

\subsection{Statistical Analysis}

A statistical software package, STATA 12 (Stata Corp LP, Texas), was used for the statistical analyses. Statistical significance was considered with a $P$-value less than 0.05 . To assess relationships between time to attainment of $100 \mathrm{~kg} \mathrm{BW}$ and farm/herd level (management) variables, univariate survival models using Kaplan-Meier (K-M) estimators and the log rank statistics were used. Time to attainment of $100 \mathrm{~kg} \mathrm{BW}$ was predicted by extrapolating the $\mathrm{BW}$ assessments between the visits before and after $100 \mathrm{~kg} \mathrm{BW}$ was attained. 15 calves had already reached $100 \mathrm{~kg} \mathrm{BW}$ at time of inclusion in the study, and these were omitted from the analyses (left censored). 3 calves were omitted because of missing BW observations, and 30 calves were omitted due to culling, selling, or because they had not reached $100 \mathrm{~kg} \mathrm{BW}$ by the end of the study.

The relationships between the natural logarithm BW (lnBW) attainment and individual level (blood parameter) variables were assessed in mixed model regression analyses, where the centered explanatory variables age and age $\times$ age were included as the second order polynomial function.

BW estimates were transformed using their natural logarithm because of the non-normality of these data, and tested as continuous variables. To avoid outliers and measurement errors, the upper and lower 2.5 percentile of the blood parameter observations were omitted prior to the statistical analyses.

Parameters with a $P$-value of less than 0.20 for the association with BW from univariate survival models and mixed models were tested in a multivariable Cox proportional hazard model (Cox regression), with shared frailty at farm level. Non-significant explanatory variables and their one way interactions were omitted by the backward elimination procedure. As the likelihood ratio test for frailty was not significant, it was also removed, and the resulting model included the explanatory variables; season of birth, water source, and blood protein content. The fit of the model was assessed with deviance residuals. The cumulative hazard function, $\log$ (-log (survival function)) for each stratum was plotted against survival time for the assessment of proportional hazard.

\section{Results}

\subsection{Association of Farm/Herd Level Factors with BW}

The results of univariate survival model using K-M for attainment of $100 \mathrm{~kg} \mathrm{BW}$ revealed that four factors were significantly related to the outcome (Table 1). These were season of birth, weaning age, drinking water source, and amount of milk fed per day. Calves born during the dry season grew faster than those born during the rainy season. The relative age difference at $100 \mathrm{~kg}$ BW between calves born during the dry and wet season is shown in Figure 1. Calves weaned at $>16$ weeks of age, reached $100 \mathrm{~kg}$ BW faster than those weaned at $<16$ weeks. The age difference between the groups as an increasing proportion of calves reached $100 \mathrm{~kg} \mathrm{BW}$ is shown in Figure 2. Calves on farms with access to surface water attained $100 \mathrm{~kg}$ at a younger age than calves

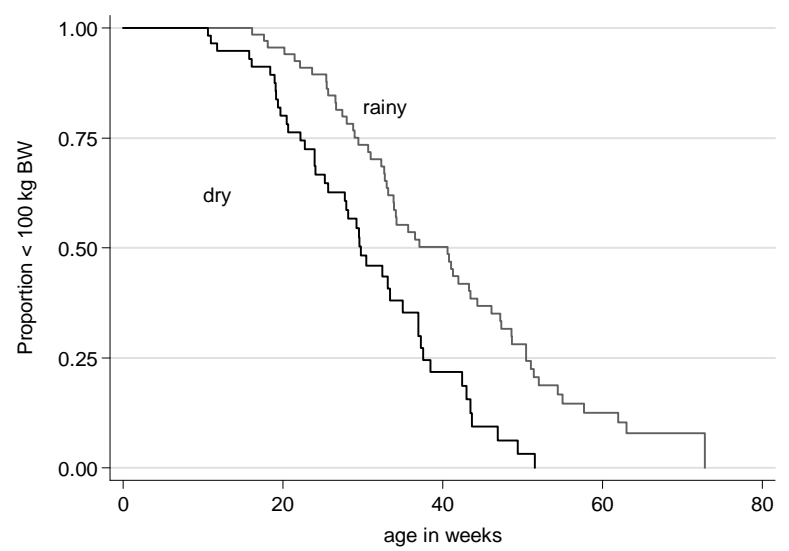

Figure 1. Kaplan-Meier plot of proportion of calves of less than $100 \mathrm{~kg}$ bodyweight ( $\mathrm{y}$-axis) by age in weeks, stratified according to season of birth.

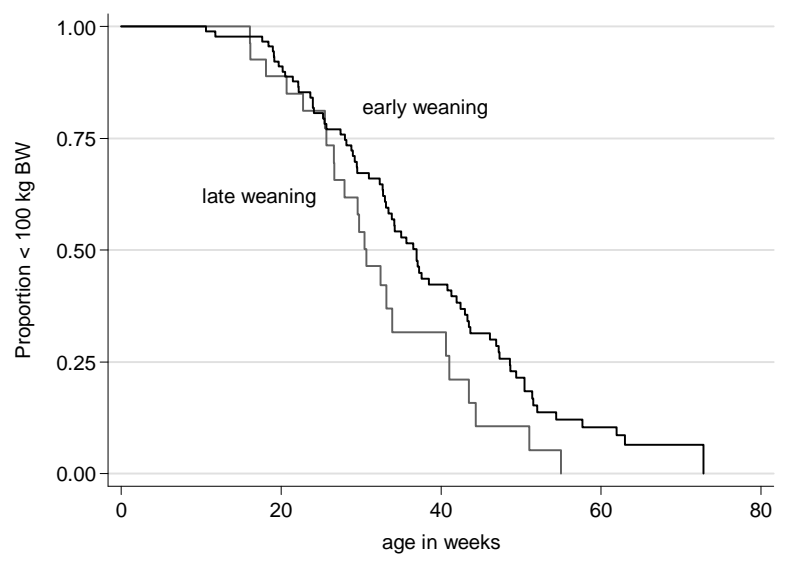

Figure 2. Kaplan-Meier plot of proportion of calves of less than $100 \mathrm{~kg}$ bodyweight (y-axis) by age in weeks, stratified according to the weaning age. 
from farms with deep wells/tap as the primary water source (Figure 3). Calves that received $>2.5 \mathrm{~kg}$ milk/day had faster growth than calves fed $2.5 \mathrm{~kg}$ of milk, or less, per day (Figure 4). Significant associations between BW attainment and other explanatory variables (district, sex, education on calf rearing, amount and time of colostrum feeding, milk feeding system, rearing of male calves, and housing conditions) were not detected using the K-M statistical analyses (Table 1).

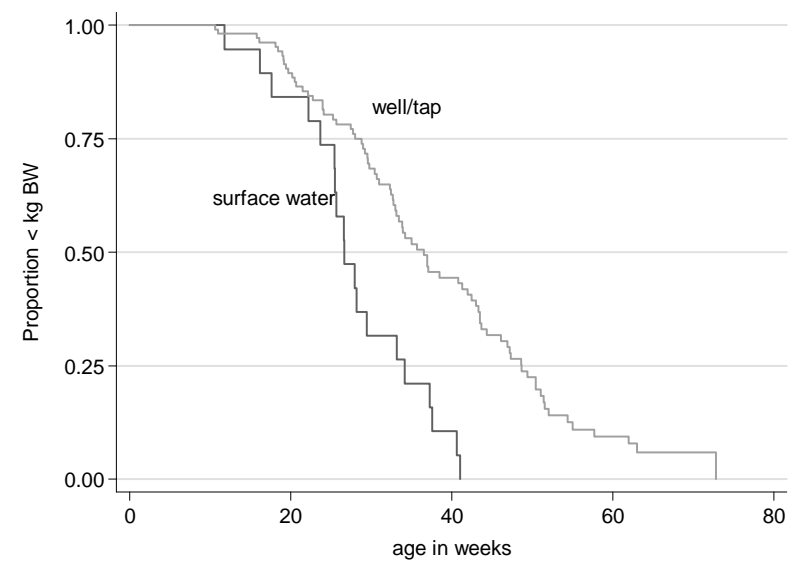

Figure 3. Kaplan-Meier plot of proportion of calves of less than $100 \mathrm{~kg}$ bodyweight (y-axis) by age in weeks, stratified according to source of drinking water.

\subsection{Association of Calf Level Factors with BW}

Of the 7 blood parameters analyzed, four were significantly associated with $\operatorname{lnBW}$, with age (centered) included as a second order polynomial covariate (Table 2). A positive relationship was observed between $\operatorname{lnBW}$ and $\mathrm{Hb}$ concentration $(P=0.005)$; an increase in plasma $\mathrm{Hb}$ concentration by $1 \mathrm{~g} / \mathrm{dl}$ (range 7.7 to 16.9 ) increased lnBW by 0.16 units (range 3.71 to 5.06 ). Thus, the model estimated that BW would be $100 \mathrm{~kg}$ in a calf with a

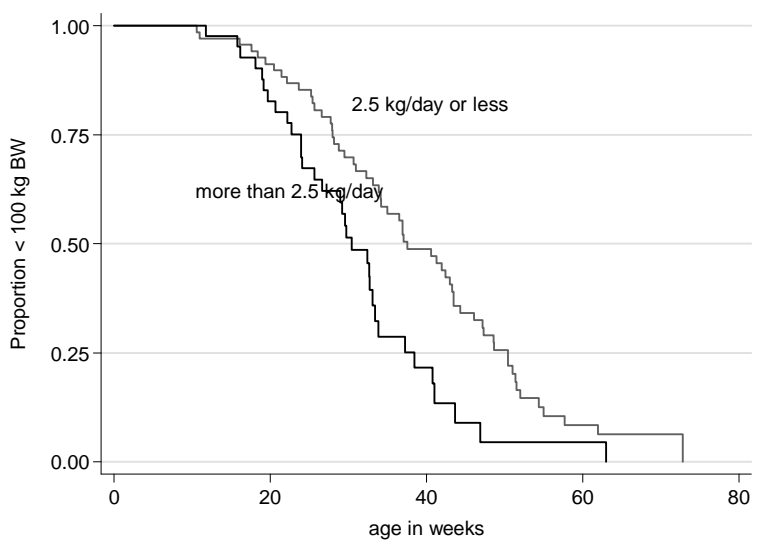

Figure 4. Kaplan-Meier plot of proportion of calves of less than $100 \mathrm{~kg}$ bodyweight (y-axis) by age in weeks, stratified according to the amount of milk fed to the calves.

Table 2. Association of calf level factors with ln bodyweight $(\mathrm{BW}, \mathrm{kg})$ based on mixed model regression analyses in calves from 121 smallholder dairy farms in Tanzania.

\begin{tabular}{|c|c|c|c|c|}
\hline Explanatory variable & Coefficient & Standard error & $\mathrm{Z}$ & $P$ value \\
\hline Hb concentration & 0.015 & 0.005 & 2.81 & 0.005 \\
\hline Age cent & 0.023 & 0.0006 & 37.82 & 0.000 \\
\hline Age square & -0.0002 & $2.5 \times 10^{-5}$ & -8.07 & 0.000 \\
\hline Constant & 4.393 & 0.065 & 67.27 & 0.000 \\
\hline Plasma protein & 0.003 & 0.001 & 2.17 & 0.030 \\
\hline Age cent & 0.023 & 0.0006 & 38.21 & 0.000 \\
\hline Age square & -0.0002 & $2.3 \times 10^{-5}$ & -8.33 & 0.000 \\
\hline Serum phosphorus & 0.031 & 0.013 & 2.41 & 0.016 \\
\hline Age cent & 0.023 & 0.0006 & 38.36 & 0.000 \\
\hline Age square & -0.0002 & $2.4 \times 10^{-5}$ & -8.65 & 0.000 \\
\hline Constant & 4.511 & 0.036 & 125.27 & 0.000 \\
\hline Serum urea & -0.016 & 0.008 & -2.03 & 0.043 \\
\hline Age cent & 0.023 & 0.0006 & 39.67 & 0.000 \\
\hline Age square & -0.0002 & $2.3 \times 10^{-5}$ & -8.14 & 0.000 \\
\hline $\mathrm{MCHC}$ & 0.002 & 0.002 & 0.99 & 0.321 \\
\hline Age cent & 0.022 & 0.0006 & 35.34 & 0.000 \\
\hline Age square & -0.0002 & $2.6 \times 10^{-5}$ & -7.38 & 0.000 \\
\hline Constant & 4.49 & 0.074 & 60.93 & 0.000 \\
\hline PCV & 0.003 & 0.003 & 1.29 & 0.196 \\
\hline Age cent & 0.023 & 0.0006 & 35.48 & 0.000 \\
\hline Age square & -0.0002 & $2.6 \times 10^{-5}$ & -8.21 & 0.000 \\
\hline Constant & 4.47 & 0.086 & 52.01 & 0.000 \\
\hline Glucose & 0.014 & 0.013 & 1.03 & 0.302 \\
\hline Age cent & 0.022 & 0.0006 & 38.24 & 0.000 \\
\hline Age square & -0.0002 & $2.6 \times 10^{-5}$ & -7.77 & 0.000 \\
\hline Constant & 4.517 & 0.056 & 81.13 & 0.000 \\
\hline
\end{tabular}

MCHC: Mean Cell Hemoglobin Concentration; PCV: Packed Cell Volume. 
plasma $\mathrm{Hb}$ concentration of $13.26 \mathrm{~g} / \mathrm{dl}$, and the $\mathrm{BW}$ of calf with a plasma $\mathrm{Hb}$ concentration of $14.39 \mathrm{~g} / \mathrm{dl}$ was predicted to be $120 \mathrm{~kg}$. Serum phosphorus concentration was also associated with $\operatorname{lnBW}(P=0.016)$; an increase of serum phosphorus concentration by $1 \mathrm{mmol} / 1$ (range 0.76 to 3.78 ) increased $\operatorname{lnBW}$ by 0.33 units. A negative relationship between $\operatorname{lnBW}$ and serum urea concentration was identified $(P=0.043)$; an increase of serum urea concentration of $1 \mathrm{mmol} / 1$ (range 0.96 to 5.75), decreased the animal $\operatorname{lnBw}$ by 0.52 units. An increase in plasma protein concentration of $1 \mathrm{~g} / \mathrm{l}$ (range 45.58 to 77.48 ) was associated with an increase in $\operatorname{lnBW}$ by 3.47 units $(P=$ 0.030) (Table 2).

\subsection{Association of Management and Calf Level Factors with BW}

When all factors were fitted into a multivariable Cox (regression) proportional hazard model using the backwards selection procedure, three factors remained significantly related to attainment of $100 \mathrm{~kg} \mathrm{BW}$. These were season of birth $(P=0.000)$, source of drinking water $(P=0.000)$, and plasma protein concentration $(P=$ 0.029) (Table 3). Keeping the effect of the other covariates constant, the likelihood (hazard ratio) of reaching $100 \mathrm{~kg} \mathrm{BW}$ was 2.17 times higher throughout the rearing period for calves born during the dry season than for those born during the rainy season. Similarly, the likelyhood (hazard ratio) of reaching $100 \mathrm{~kg}$ BW was 3.25 times higher in calves using surface water than in calves drinking well/tap water. The model predicted an increased likelihood of 1.03 (3\%) of achieving $100 \mathrm{~kg} \mathrm{BW}$ for each $1 \mathrm{~g} / \mathrm{l}$ increase of plasma protein concentration.

\section{Discussion}

Various factors at both the farm-level and the calf-level were found to be associated with retarded growth and slow attainment of BW in the smallholder farms included in the study. Early weaning (before 4 months of age) was a farm factor associated with retarded growth. Although previous reports state that, under good management, dairy calves can be safely weaned as early as $7-8$ weeks

Table 3. Herd and calf level variables significantly associated with bodyweight (BW) attainment based on multivariable analysis using Cox regression in 121 smallholder dairy farms in Tanzania.

\begin{tabular}{ccccc}
\hline Variable & $\begin{array}{c}\text { Hazard } \\
\text { ratio }\end{array}$ & $\begin{array}{c}\text { Standard } \\
\text { error }\end{array}$ & $\mathrm{Z}$ & $P$ value \\
\hline Season of birth & 2.17 & 0.47 & 3.57 & 0.000 \\
$\begin{array}{c}\text { Source of } \\
\text { drinking water }\end{array}$ & 3.25 & 0.90 & 4.26 & 0.000 \\
$\begin{array}{c}\text { Plasma protein } \\
\text { concentration }\end{array}$ & 1.03 & 1.03 & 2.18 & 0.029 \\
\hline
\end{tabular}

of age [17], the lack of availability of good quality concentrate to feed the calves in this area [2] probably means that later weaning would be beneficial in Tanzania and other areas where concentrate availability is a limiting factor. In early life, calves cannot utilize high fiber feeds efficiently [18], but good quality concentrate early in life enhances nutrient supply to the calf and is necessary for early weaning to be successful [19].

In this study, calves that received $>2.5 \mathrm{~kg}$ of milk/day had faster growth; adequate milk intake by calves during the first 3 months of age is recognized as being very important for good health and fast growth rates [20]. Although the majority of smallholder dairy farmers in the study allowed their calves to suckle at least twice a day during the lactation period, competition for milk between the calf and marketplace is relatively common, especially when there is a ready market for milk [21]. Educating farmers on the importance of adequate milk intake for improving calf growth is recommended.

The increased BW of calves born during the dry season is intriguing. It is likely that for calves born during the dry season, the majority of their growth actually occurs in the rainy/wet season when feed quality and availability is greatest. This observation may have implications for future breeding strategies. The positive effects of the wet season have also been reported by de Leeuw et al. [21], who found that calves entering the long dry season (July-November) at an early age experienced growth retardation, due to prolonged exposure to poor pastures.

Reasons for variations in BW attainment in calves using different drinking water sources are also interesting, and different scenarios may explain our observations. It could be that farmers that used tap and deep water as drinking water sources for their calves had water supply limitations, especially during the dry season, and therefore water supply was already restricted. Water shortages are common in these regions during the dry season. Animals using surface water as their main drinking water supply may have been able to drink ad libitum. Increased watering frequency has previously been associated with increased average daily weight gain in calves due to the associated increase in feed intake [22,23]. Thus, farmers should be made aware of the importance of providing adequate clean water to calves to improve calf growth rate.

Low BW gain was also associated with low plasma $\mathrm{Hb}$ concentration, as has previously been reported [24], from a study in which a significant correlation between $\mathrm{Hb}$ level and BW gain in calves was observed. Low $\mathrm{Hb}$ concentration affects many systems through reduction in tissue oxygenation. $\mathrm{Hb}$ is synthesized in the bone marrow from iron $(\mathrm{Fe})$ and protein, and therefore $\mathrm{Hb}$ synthesis can be impaired by Fe deficiency (caused by substrate 
insufficiency for ferrochelatase [11], by copper $(\mathrm{Cu})$ deficiency resulting in decreased activity of the $\mathrm{Cu}$-dependent enzyme cytochrome oxidase [11], or by protein deficiency). In a previous study of smallholder dairy cows in Morogoro, Tanzania, feed resources had sufficient concentrations of $\mathrm{Fe}$ in all seasons, but mean plasma $\mathrm{Fe}$ and $\mathrm{Cu}$ concentrations were nevertheless below the critical levels [25]. Low plasma Fe concentrations could be due to low Fe absorption efficiency or due to the proportions of other minerals and compounds that interact with $\mathrm{Fe}$ in the diet, for example, low plasma $\mathrm{Cu}$ concentrations [26,27]. Indeed, low concentrations of $\mathrm{Cu}$ have been reported in both natural forage and in crop residues [28]. However protein deficiency is also common, as the forages are low in crude protein [28] and protein concentrate supplements are insufficient [29,30], and this also could be a relevant factor in our study. Therefore, dietary protein supplementation is recommended to address $\mathrm{Hb}$ deficiency and to promote calf growth.

Low total plasma protein concentrations were also associated with low BW in this study, reinforcing the importance of protein for calf growth, as previously discussed [2]. Providing an appropriate supply of amino acids to dairy calves is important for ensuring rapid structural growth and lean tissue deposition. Blome et al. [13] found that, BW gain and gain: feed ratio increased linearly as dietary crude protein increased. Cultivation of forage legumes by farmers should be encouraged in order that a sufficiently protein-rich diet is available for young dairy calves.

Low concentrations of phosphorus in the serum were also shown to be associated with low BW in this study. In phosphorus deficiency, feed is utilized less efficiently, presumably due to disturbances in energy metabolism [11], and will result in reduced weight gain. Phosphorus deficiency in ruminants is probably due to low concentrations of this element in the forage. For most of the year, mature forages in tropics contain less than $0.15 \%$ phosphorus, which is lower than the required value $[10,31]$, and in most areas of Tanzania, soil and plants are low in phosphorus $[28,32,33]$. However, other studies in Tanzania have found that the concentration of phosphorus in feed resources was adequate to meet cow requirements, although it decreased during the dry season $[25,34]$. Feed grains and seed byproducts, such as rice bran and the oilseed meals, are rich in phosphorus $[25,28]$, and therefore farmers should be encouraged to supply their calves with adequate amounts of concentrate to avoid phosphorus deficiency.

High concentrations of urea in serum were associated with low growth rate, possibly indicating a lack of energy in the animal ration. When peptide availability exceeds glucose availability in the ruminant gut, although there is ample nitrogen to support microbial growth, growth is limited because of insufficient energy supplies [12]. These conditions force the microbes to use peptides to meet energy needs instead of for protein synthesis. When the microbial growth rate is low, the amine groups are shunted to ammonia production, causing ruminal ammonia levels to rise. The ammonia is absorbed from the rumen, and results in increased blood urea concentrations [12]. Lyimo et al. [30] reported that calves in smallholder farms were fed natural forages alone, which are of low digestibility and has low dry matter content $[28,35]$. We anticipating that, our farmers behaved as did the farmers in the Lyimo [30] study who found that, the only supplement was maize bran, of which very little or none was provided to the calves because they were not regarded as important as lactating cows [30]. The high serum urea concentrations observed in our study may be a consequence of this feeding strategy that results in insufficient energy supply in the animal feed for calves. Selection of appropriate forages for a particular season, together with provision of concentrate supplements, is important for optimum weight gain and good performance.

In summary, in this study area, the most important management factors associated with dairy calf $\mathrm{BW}$ attainment were season of birth, amount of milk fed to calves, source of drinking water, and weaning age. In addition, $\mathrm{Hb}$ concentration, serum phosphorus and urea concentrations, and plasma protein levels are calf-level variables that are associated with BW attainment. As the smallholder farmers in this area raise their own replacement stock and have small herd sizes, we recommend that an educational initiative with particular emphasis on the amount of milk fed to calves, management of weaning calves, provision of adequate water, and supply of nutritious protein and mineral feed would be beneficial for calf health and herd productivity. In addition, improvements in calf growth might also be achieved by approaches such as seasonal breeding strategies, introduction of supplementary feeding practices, and by improving livestock extension services.

\section{Acknowledgements}

The authors acknowledge the financial support given by the Norwegian Government through the PANTIL project at Sokoine University of Agriculture. We also acknowledge the cooperation from dairy farmers participating in the study and field officers in Mvomero and Njombe districts.

\section{REFERENCES}

[1] B. Drew, "Targets for Rearing Dairy Heifers-Weaning to Calving," In Practice, Vol. 20, No. 1, 1998, pp. 35-39. doi:10.1136/inpract.20.1.35 
[2] J. S. Chang'a, O. Reksen, T. Løken and R. H Mdegela, "Calf Health and Growth in Smallholder Dairy Farms in Tanzania," Livestock Research for Rural Development Vol. 23, No. 156, 2011, 8 p.

http://www.lrrd.org/lrrd23/7/chan23156.htm

[3] L. Doeppel, R. Corbett and M. Schoonderwoerd, "Milk Replacers," In: B. P. Smith, Ed., Large Animal Internal Medicine, Mosby, St. Louis, Missouri, 1996.

[4] C. L. Davis and J. K. Drackley, "The Development, Nutrition and Management of the Young Calf," 1st Edition, Iowa State University Press, Ames, 1998.

[5] P. C. Hoffman and D. A. Funk, "Applied Dynamics of Dairy Replacement Growth and Management," Journal of Dairy Science, Vol. 75, No. 9, 1992, pp. 2504-2516. doi:10.3168/jds.S0022-0302(92)78012-6

[6] Y. N. Msanga and M. J. Bryant, "Productivity of Crossbred Dairy Cows Suckling Their Calves for 12 or 24 Weeks Post Calving," Tropical Animal Health and Production, Vol. 36, No. 8, 2004, pp. 763-773. doi:10.1023/B:TROP.0000045961.40291.84

[7] A. G. Sidibe-Anago, G. A. Ouedraogo and I. Ledin, "Effect of Suckling Period on Calf Growth and Milk Yield of Zebu Cows," Tropical Animal Health and Production, Vol. 40, No. 7, 2008, pp. 491-499. doi:10.1007/s11250-007-9125-y

[8] M. A. Thrall, "Veterinary Hematology and Clinical Chemistry," 2nd Edition, Blackwell Publishing, Lippincott Williams and Wilkins, Philadelphia, 2006.

[9] J. W. Spears, "Trace Minerals in Ruminant Nutrition," Animal Feed Science Technology, Vol. 58, 1996, pp. 115163. doi:10.1016/0377-8401(95)00881-0

[10] E. J. Underwood, "The Mineral Nutrition of Livestock," Commonwealth Agricultural Bureaux, London, 1981.

[11] L. R. McDowell, "Minerals in Animal and Human Nutrition," Academic Press, San Diego, 1992.

[12] J. G. Cunningham and G. K. Brabley, "Textbook of Veterinary Physiology,” 4th Edition, Saunders, 2007.

[13] R. M. Blome, J. K. Drackley, K. F. McKeith, M. F. Hutjens and G. C. McCoy, "Growth, Nutrient Utilization, and Body Composition of Dairy Calves Fed Milk Replacers Containing Different Amounts of Protein," Journal of Animal Science, Vol. 81, 2003, pp. 1641-1655. http://jas.fass.org/content/81/6/1641.full.pdf

[14] S. M. Das, H. Wiktorsson and M. Forsberg, "Effects of Calf Management and Level of Feed Supplementation on Milk Yield and Calf Growth of Zebu and Crossbred Cattle in the Semi Arid Tropics," Livestock Production Science, Vol. 59, No. 1, 1999, pp. 67-75. doi:10.1016/S0301-6226(98)00206-1

[15] J. S. Chang'a, R. H. Mdegela, R. Ryoba, T. Løken and O. Reksen, "Calf Health and Management in Smallholder Dairy Farms in Tanzania," Tropical Animal Health and Production, Vol. 42, No. 8, 2010, pp. 1669-1676. doi:10.1007/s11250-010-9619-x

[16] F. J. Baker and R. E. Silverton, "Introduction to Medical Laboratory Technology," Botteworths, London, 1976, $736 \mathrm{p}$.

[17] A. J. Heinrichs and O. M. Radostits, "Health and Produc- tion Management of Dairy Calves and Replacement Heifers," In: O. M. Radostits, Ed., Herd Health, Food Animal Production Medicine, 3rd Edition, W.B. Saunders Company, Philadelphia, 2001, pp. 333-395.

[18] D. E. Otterby and J. G. Linn, "Advances in Nutrition and Management of Calves and Heifers," Journal of Dairy Science, Vol. 64, 1981, pp. 1365-1377. doi:10.3168/jds.S0022-0302(81)82709-9

[19] G. Y. Berhane, "The Study of Performance of Dairy Calves Fed Soybean and Fish Meal Based Calf Starter Ration and Weaned at Different Ages," Tanzania Journal of Agricultural Science, Vol. 1, 1998, pp. 42-49.

[20] M. C. Sharma and R. R. Mishra, "Livestock Health and Management," Khanna Publishers, New Delhi, 1987.

[21] P. N. De Leeuw, S. Bekure and B. E. Grandin, “Aspects of Livestock Productivity in Maasai Group Ranches in Kenya," ILCA Bulletin, Vol. 19, 1984, pp. 17-20.

[22] S. Bekure, P. N. de Leeuw, G. E. Grandin and P. J. H. Neate, "Maasai Herding: An Analysis of the Livestock Production System of Maasai Pastoralists in Eastern Kajiado District, Kenya," ILCA Systems Study 4, ILCA (International Livestock Centre for Africa), Addis Ababa, Ethiopia, 1991, 72 p.

[23] D. L. Coppock, "The Borana Plateau of Southern Ethiopia: Synthesis of Pastoral Research, Development and Change," 1980-91, ILCA Systems Study, Addis Ababa, Ethiopia, 1994, pp. 1-393.

[24] J. W. Thomas, M. Okamoto, W. C. Jacobson and L. A. Moore, "A Study of Hemoglobin Levels in the Blood of Young Dairy Calves and the Alleviation of Anemia by Iron," American Dairy Science Association, Vol. 91, 1994, pp. 330-332.

[25] D. J. Mtui, L. S. B. Mellau, F. P. Lekule, M. N. Shem, M. Hayashida and T. Fujihara, "Seasonal Influence on Mineral Concentrations in Dairy Cows' Blood and Feed Resources Collected from Morogoro, Tanzania," Journal of Food, Agriculture and Environment, Vol. 3-4, No. 5, 2007, pp. 274-280.

[26] E. J. Underwood and N. F. Suttle, "The Mineral Nutrition of Livestock," 3rd Edition, CABI Publishing, Oxon, 1999. doi: $10.1079 / 9780851991283.0000$

[27] NRC (National Research Council), "Nutrient Requirements of Domestic Animals," 7th Edition, National Academy Press, Washington DC, 2001.

[28] E. Mtengeti, E. Phiri, D. G. Urio, Z. Mhando, R. Mvena, R. Ryoba, R. Mdegela, M. Singh, T. Wetlesen, T. Løken and O. Reksen, "Forage Availability and Its Quality in the Dry Season on Smallholder Dairy Farms in Tanzania," Acta Agriculturae Scandinavica, Vol. 58, No. 4, 2008, pp. 196-204. doi:10.1080/09064700802492362

[29] L. A. Mtenga, R. P. Mbwile, A. E. Pereka, G. H. Laswai and R. T. Chibunda, "A Report on Inventory of Livestock Husbandry Practices in Selected Villages in Njombe District," Tanzania Agricultural Research Phase II, Sokoine University of Agriculture (TARP II-SUA) Project, Tanzania, 2001, 42 p.

[30] H. L. N. Lyimo, L. A. Mtenga, A. E. Kimambo, T. Hveplund, G. H. Laswai and M. R. Weisbjerg, "A Survey on 
Calf Feeding Systems, Problems and Improvement Options Available for the Smallholder Dairy Farmers of Turiani in Tanzania," Livestock Research for Rural Development, Vol. 16, No. 4, 2004, 23 p.

[31] H. Harricharan, J. Morris and C. Devers, "Mineral Content of Some Tropical Forage Legumes," Tropical Agriculture, Vol. 65, No. 2, 1998, pp. 132-136.

[32] A. E. Pereka and E. C. Phiri, "Mineral Content in Soils and Pastures Grasses at ASAS Farm, Iringa, Tanzania," Tanzania Veterinary Journal, Vol. 18, No. 1, 1998, pp. 101-109.

[33] C. D. K. Rubanza, M. N. Shem, S. S. Bakengesa, , T. Ichinohe and T. Fujihara, "Content of Macro and Micro Minerals of Deferred Forages in Silvo-Pastoral Traditional Fodder Banks (Ngitiri) of Meatu District of Central
North-Western Tanzania," Livestock Research for Rural Development, Vol. 17, No. 141, 2005, 9 p.

[34] B. M. Msanya, A. K. Kaaya, S. Araki, H. Otsuka and G. I. Nyadzi, "Pedological Characteristics, General Fertility and Classification of Some Benchmark Soils of Morogoro District Tanzania," African Journal of Science and Technology Science and Engineering Series, Vol. 2, No. 4, 2003, pp. 101-112.

[35] R. P. Mbwile, "Rhodes grass (Chloris gayana kunth) Effects of Age and Season on Growth, Chemical Composition and Digestibility and on Selective Intake by Dairy Cows," Department of Animal Nutrition and Management, Swedish University of Agriculture Science, Uppsala, Sweden, Report 200, 1990, 100 p. 